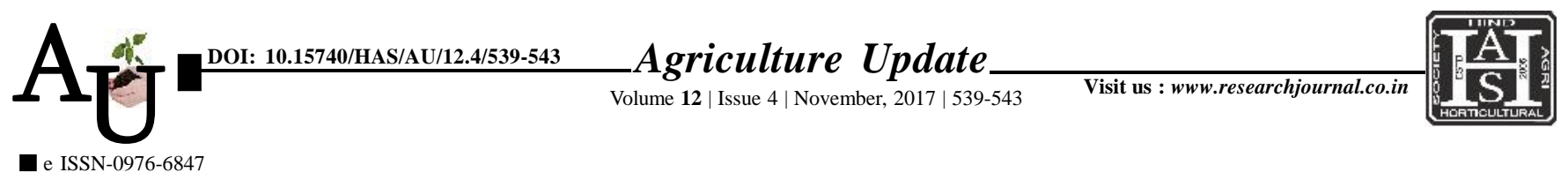

\title{
Rевевсни автісі: Role of Gram Panchayat members in village development
}

\section{SHILPA S. PATLE, A.N. DESHMUKH, S.A. DESHMUKH AND N.B. LOTHE}

Article Chronicle:

Received :

17.06.2017;

Revised :

21.08.2017;

Accepted :

07.09.2017

KEY Words:

Gram panchayat,

Panchayat raj, Role

performance, Village

development

Author for correspondence :

\section{SHILPA S. PATLE}

Department of

Extension Education,

Shri Shivaji Agriculture

College, AMRAVATI (M.S.)

INDIA

See end of the article for

authors' affiliations
SUMMARY : The study on role of Gram Panchayat members in village development was undertaken in Amravati Panchayat Samiti in the Amravati district of Maharashtra state. In Maharashtra Gram means village. The 80 Gram Panchayat member were selected by simple random sampling method from 9 villages in Amravati Panchayat Samiti. The data were collected by personal interview method with the help of interview schedule. Careful analysis, tabulation and classification of the data were done. Mean, standard deviation, frequency, percentage and correlation of the data were employed for the interpretation of the results. Results obtained after analysis are summariesd as below. In case of personnal, socioeconomic, economic and psychological characteristics of the Gram Panchayat members indicated that majority of the respondents (46.25\%) were found middle age in between 36 to 50 years, $52.5 \%$ were educated upto higher secondary/Graduate level. Majority of the respondents were found living in nuclear family size (65.00\%), had medium level of cosmopolitness (75.00\%), 57.5 per cent of the respondents had medium level of social participation and $(65.00 \%)$ of the respondents had medium socio-economic status. Whereas, high work experience $(65.00 \%)$. Majority of the respondents $(60.00 \%)$ were having medium role performance. The relationship of the selected variable i.e. age, education, cosmopolitness, social participation and socio-economic status had positive and significant relationship with role performance. Variables size of family and work experience had non significant with role performance. The major constraints faced during the Role performance of Gram Panchayat members were found that non availability of developmental fund in timely $(88.75 \%)$, lack of cooperation by villagers and grampanchayat members $(70.00 \%)$, rigid casteism $(75.00 \%)$, negligence of government agencies $(61.25 \%)$, lack of training and information technology (40,00\%). Most of respondents suggested to increase financial support by the government, increasing taxes on weekly bazaar and active cooperation by extension agencies and villagers.

How to cite this article : Patle, Shilpa S., Deshmukh, A.N., Deshmukh, S.A. and Lothe, N.B. (2017). Role of Gram Panchayat members in village development. Agric. Update, 12(4): 539-543; DOI : 10.15740/HAS/AU/ 12.4/539-543. 